File 2757, 43(4) 2nd Print (1)

Avaiable online at www.banglajol.info

Bangladesh J. Sci. Ind. Res. 43(4), 495-500, 2008

BCSIR

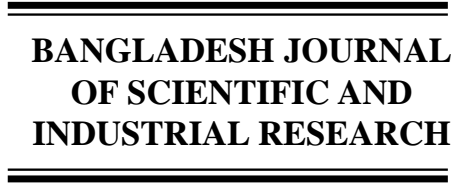

E-mail: bjsir07gmail.com

\title{
Investigation on the Occurrence of Ochratoxin A in Maize in Bangladesh
}

\author{
M. Dawlatana ${ }^{a}$, S. Shahida ${ }^{a}$, Matiur Rahim ${ }^{\mathrm{a}}$ and M. Tariqul Hassan ${ }^{\mathrm{a}}$ \\ ${ }^{a}$ Food Toxicology Research Section, Institute of Food Science and Technology (IFST), \\ BCSIR, Dhanmondi, Dhaka-1205, Bangladesh.
}

\begin{abstract}
Maize was collected from different markets of Bangladesh for the determination of ochratoxin A. Simultaneously controlled maize samples were analyzed to assess the ochratoxin A level of market samples and that of controlled samples. A total of 120 samples were analyzed to determine ochratoxin A including 70 market samples and 50 controlled samples. Market samples were found containing a high contamination level of ochratoxin A ranged from 1 to $117 \mu \mathrm{g} / \mathrm{kg}$ and incidence rate was $40 \%$ whereas in the controlled samples the contamination rate was found very low ranged from 3 to $9 \mu \mathrm{g} / \mathrm{kg}$ and the incidence rate was found $10 \%$ only.
\end{abstract}

Key words : Maize, Ochratoxin A, Occurrence, Bangladesh, HPTLC

\section{Introduction}

Mycotoxins are secondary metabolites (byproducts) produced by various generations of fungi when they grow on agricultural products before or after harvest or during transportation or storage. In general, they are differentiated between field and storage fungi.
Ochratoxin A, a naturally occurring mycotoxin, is produced by certain species of Aspergillus and Penicillium fungi. The natural occurrence of this toxin in grains and other plant products has been widely reported (Herwig and Scott, 1995; Kuiper- and Scott et al, 1989; StÆrmer 1992). Feeding experimental diets containing ochratoxin A 
have a deleterious effect on a number of animal species. Biological and biochemical effects associated with ochratoxin A include; teratogenicity, nephropathy, enhancement of lipid peroxidation, partial inhibition of ATPdependent calcium uptake, carcinogenicity and inhibition of cell-mediated immune response (Kuiper-and Scott 1989; StÆrmer FC, 1992).

Human exposure to ochratoxin A can occur directly by consumption of contaminated plant derived food or indirectly by consumption of animal tissues from livestock exposed to contaminated materials (PetkovaBocharova et al, 1988).

Bangladesh is a tropical and rainfull country. Recently, maize has been introduced as a good source of both food and feed. Although primarily produced as an ingredient of poultry feed, maize is increasingly being consumed as a human food.

The aim of this study was to evaluate the level of contamination of ochratoxin $A$ in maize of Bangladesh and find out the ways of remedial measures.

\section{Materials and Methods}

\section{Sampling}

Samples collected for investigation were mainly of two types. One type was collected from open market while the second type (controlled samples) was taken from the store (under specific condition) of Institute of Food Science \& Technology (IFST), BCSIR, Dhaka. Open market samples were collected from different markets of the districts of Rajshahi, Khulna, Comilla and Dinajpur. Controlled samples were mainly the samples stored under required conditions by the IFST, BCSIR, Dhaka. Controlled samples were collected time to time from IFST.

\section{Sample preparation}

A $10 \mathrm{~kg}$ sample was collected in each lot from time to time from different markets and different stores. Each sample was sub-divided into $1 \mathrm{~kg}$ sub-sample in a rotary cascade sample divider and powdered in a sub-sampling mill by simplable variable speed drive to collect $200 \mathrm{~g}$ representative sample.

The analytical methods employed solid phase extraction clean-up and quantification using HPTLC procedures specifically developed and validated for use in this study (Soares and Rodrignes, 1989).

\section{Results and Discussion}

During the one year study period a total of 120 samples were analyzed for ochratoxin A. 
Samples collected from the markets of Rajshahi, Khulna, Comilla and Dinajpur districts showed the level of ochratoxin A ranged from 1-15 $\mu \mathrm{g} / \mathrm{kg}, 1-103 \mu \mathrm{g} / \mathrm{kg}$, and 1$117 \mu \mathrm{g} / \mathrm{kg}$ respectively (Table I). tion of ochratoxin A. Only 5 samples out of 50 storage maize samples were found to be contaminated with ochratoxin A ranged between $3-9 \mu \mathrm{g} / \mathrm{kg}$. Less moisture content was found in controlled stored samples. As a

Table I: Level of ochratoxin A and moisture content of market samples

\begin{tabular}{l|c|c|c|c}
\hline Collection area & $\begin{array}{c}\text { No. of } \\
\text { samples } \\
\text { analyzed }\end{array}$ & $\begin{array}{c}\text { Level of } \\
\text { moisture content } \\
(\%)\end{array}$ & $\begin{array}{c}\text { No. of } \\
\text { positive } \\
\text { samples }\end{array}$ & $\begin{array}{c}\text { Level of } \\
\text { total ochratoxin A } \\
\mu \mathrm{g} / \mathrm{kg}\end{array}$ \\
\hline Rajshahi & 20 & $11.51-17.85$ & 8 & $1-78$ \\
Khulna & 15 & $11.35-14.36$ & 3 & $1-15$ \\
Comilla & 15 & $10.15-18.70$ & 6 & $1-103$ \\
Dinajpur & 20 & $10.38-17.15$ & 11 & $1-117$ \\
\hline
\end{tabular}

A total of 70 samples collected from different markets of four districts of Bangladesh showed that 28 samples were contaminated with ochratoxin A and incidence rate of $40 \%$ (Table II).

A total of 50 samples taken from different containers were analyzed for the determina result of that ochratoxin A was not found in controlled stored samples (Table III).

Table IV shows that incidence rate of ochratoxin A of maize samples were found $30 \%$ in Tin, $0 \%$ in Motka, 0\% in Dola, 20\% in Jute Bag and $0 \%$ in controlled stored sample respectively.

Table II: Ochratoxin A incidence rate of market samples

\begin{tabular}{c|c|c|c}
\hline \multirow{2}{*}{ Collection area } & Samples analyzed & \multicolumn{2}{|c}{ Ochratoxin A } \\
\cline { 3 - 4 } & & $\begin{array}{c}\text { Sample } \\
\text { contaminated }\end{array}$ & $\begin{array}{c}\text { Incidence rate } \\
\text { (\%) }\end{array}$ \\
\hline Rajshahi & 20 & 8 & 40 \\
Khulna & 15 & 3 & 20 \\
Comilla & 15 & 6 & 40 \\
Dinajpur & 20 & 11 & 55 \\
Total & 70 & 28 & 40 \\
\hline
\end{tabular}


Table III : Ochratoxin A level and moisture content of stored samples of maize

\begin{tabular}{l|c|c|c|c}
\hline Container type & $\begin{array}{c}\text { No. of sample } \\
\text { analyzed }\end{array}$ & $\begin{array}{c}\text { Level of moisture } \\
\text { content (\%) }\end{array}$ & $\begin{array}{c}\text { No. of positive } \\
\text { samples }\end{array}$ & $\begin{array}{c}\text { Level of } \\
\text { ochratoxin A } \\
(\mu \mathrm{g} / \mathrm{kg})\end{array}$ \\
\hline Tin & 10 & $11.08-16.09$ & 3 & $4-6-8$ \\
Motka & 10 & $10.07-12.05$ & 0 & 0 \\
Dola & 10 & $11.21-13.05$ & 0 & 0 \\
Jute Bag & 10 & $12.51-14.05$ & 2 & $3-9$ \\
Controlled stored & 10 & $8.01-9.05$ & 0 & 0 \\
samples & & & & \\
\hline
\end{tabular}

Table 4: Incidence rate of Ochratoxin $A$ in controlled samples

\begin{tabular}{l|c|c|c}
\hline \multirow{2}{*}{ Container type } & $\begin{array}{c}\text { No. of } \\
\text { Samples analyzed }\end{array}$ & $\begin{array}{c}\text { Sample } \\
\text { contaminated }\end{array}$ & $\begin{array}{c}\text { Incidence rate } \\
\text { (\%) }\end{array}$ \\
\cline { 3 - 4 } & 10 & 3 & 30 \\
Tin & 10 & 0 & 0 \\
Motka & 10 & 0 & 0 \\
Dola & 10 & 2 & 20 \\
Jute Bag & 10 & 0 & 0 \\
Controlled stored & & 5 & 10 \\
sample & 50 & 5 & \\
Total & &
\end{tabular}

It is clear that the instructed material of the stored container has an influence of ochratoxin A contamination. Out of 10 samples taken from the containers only 3 samples were found to contain $4 \mu \mathrm{g} / \mathrm{kg}, 6 \mu \mathrm{g} / \mathrm{kg}$ and $8 \mu \mathrm{g} / \mathrm{kg}$ ochratoxin A respectively.

\section{Conclusion}

Incidence rate of ochratoxin A in stored sample is very low comparing to market sample.
A total of only 5 samples out of 50 samples were found contaminated by ochratoxin A. The incidence rate of ochratoxin A was found $10 \%$ in stored samples whereas the incidence rate of market samples was found to be $40 \%$.

Proper storage is necessary to overcome the contamination of ochratoxin A in maize. 


\section{Acknowledgements}

Highly acknowledgement to the authority of BCSIR for the reason they have approved this research work. Authority of the IFST is also being acknowledged for their kind cooperation during the project implementation.

\section{References}

Bauer, J. Gareis, M. (1987) Ochratoxin in der Nahrungsmittelkette. J Vet Med (Ser B) 34: 613-27.

Biacardi, A. Riberzani, A. (1996) Determination of ochratoxin A in cereals and feeds by sax-spe clean up and LC fluorimetric detection. $\mathrm{X}$ International IUPAC Symposium on Mycotoxins and Phycotoxins, Roma, 314.

Dunne, C. Meaney, M. Smyth, M. Tuinstra, LGMT. (1993) Multimycotoxin detection and clean-up method for aflatoxins, ochratoxin and zearalenone in animal feed ingredients using high-performance liquid chromatography and gel permeation chromatography. J Chromatogr 629: 229-35.

Hald, B. Wood, G.M. Boenke, A. Schurer, B. Finglas, P. (1993) Ochratoxin A in wheat: An intercomparison of procedures. Food Addit Contam 10: 185-207.
Herwig, J. Kuiper-Goodman, T. Scott, PM. (1995) Microbial Food Toxicants: Ochratoxins. In: Rechcig IM (ED.) Handbook of Foodborne Diseases of Biological Origin.Boca Raton, CRC Press, 193-238.

Hult, K. Hokby, E. Sellyey, G. Rutqvist, L. Gatenbeck, S. (1992) Ochratoxin A occurrence in slaughter-pigs in Sweden and its use as a tool for feed screening programs. J Environ Pathol Toxicol Oncol 11: 103-4.

Kuiper-G. T. Scott, PM. (1989) Risk assessment of the mycotoxin ochratoxin A. Biomed Environment Sci 2: 79-248.

Nesheim, S. Stack, M.E. Trucksess, M. Eppley, RM. Krogh, P. (1992) Rapid solvent-efficient method for liquid chromatographic determination of ochratoxin A in corn, barley, and kidney: collaborative study. $J$ Amer OAC Int 75: 481-7.

Petkova-B. T. Chernozemsky, I.N. Castegnaro, M. (1988) Ochratoxin A in human blood in relation to Balkan endemic nephropathy an urinary system tumors in Bulgaria.Food Addit Contam 5: 299-301.

Seidal, V. Poglits, E. Schiller, K. Lindner, W. (1993) Simultanius determination of ochratoxin A and zearalenone in maize by reversed-phase high-performance liquid 
chromatography with fluorescence detection and b-cyclodextrin as mobile phase additive. Journal of Chromatogr 635: 22735.

Soares LMV, Rodriguez-Amaya DB (1989). "Survey of Aflatoxin, Ochratoxin A, Zearalenone, and Sterigmatocystin in Some Brazilian Foods by Using Multitoxin Thin-Layer Chromatographic Method . J.assoc. Off. Anal. Chem. 72(1): 22-26.
St $Æ$ rmer, F.C. Ochratoxin, A- (1992) A mycotoxin of concern. In: Bhatnagar D. Lillehoj EB, Arora DK, (Eds.). Handbook of Applied Mycology. Mycotoxins in Ecological Systems. New York, Marcel Dekker Inc, 403-32.

Trucksess MW. Mycotoxins. J Am OAC Int 1995; 78: 135-41.

Received : March, 20, 2008;

Accepted : August, 06, 2008 